poor environment in which so many humans exist. For scientists to advocate channelling resources uncritically, as this book seems to $\mathrm{do}$, is to risk bringing genetic research into public disrepute.

Whatever the true mechanism, perhaps Lord Kelvin was not so misguided after all in his faith in the goodness of "benevolent design". As a Christian he might have asked: if we change the very nature of what it is to be a human, will we still have our humanity? Robert Winston is at the Institute of Reproductive and Developmental Biology, Hammersmith Hospital, Imperial College, London W12 OHS, UK

\section{Flexing our muscle}

\section{power}

\section{Prime Mover: A Natural History of Muscle \\ by Steven Vogel \\ W. W. Norton: 2002. 351 pp. \$25.95, £19.95 \\ R. McNeill Alexander}

Steven Vogel tells us that his professional biases, as a biologist, "start with the belief that we just can't understand history, literature, economics, art, and so forth without taking biology into consideration". Accordingly, in his book he asks what muscle physiology may reveal about human history, prehistory and culture. He is concerned with the human body, with the tools, vehicles and weapons that are powered by our muscles rather than by motors, and with the use that people make of the muscle power of animals.

To do this effectively in a book for general readers, Vogel has to use six of his 15 chapters to describe basic muscle physiology. He explains the sliding-filament mechanism of muscle contraction, the relationship between force, speed of shortening of muscle fibres and power output, and the energy cost and (in)efficiency of muscular work. He tells us about the red muscles, such as the breast meat of pigeons, that can continue working for long periods, and the white muscles of chicken breast, which are good only for short bursts of activity. We learn how the reflexes work, helping us to control movements, and how a slender muscle can exert large forces if it is built from a very large number of short muscle fibres converging on tendons.

All this is done clearly, in the readable prose that distinguishes Vogel's books, and with an attractive historical perspective. As well as being a distinguished research scientist in the field of biomechanics, Vogel is one of the best semi-popular writers on biology. He has an outstanding ability to be simple and entertaining without being misleading.

By the end of chapter 6, Vogel has got us through the basics. He has also dealt with a few of the implications of the physiology, which are the main topic of his book. For instance, we know about the extraordinary surgical operation of cardiomyoplasty, in which a dispensable shoulder muscle is wrapped around an ailing heart and stimulated to help it pump blood. And we have been shown how the elastic recoil of stretched tendons can save energy in running, or give a catapult-like boost to a jump.

Up to this point, general readers will have learned a lot but physiologists very little. The rest of the book is written at the same nontechnical level, but will give almost everyone something to think about. Vogel discusses a wide variety of hand tools, using the physiology explained in the earlier chapters in conjunction with simple engineering mechanics. He discusses our use of tools ranging from pliers to corkscrews, which amplify the force that we can exert. We discover why wood is a good material for axe handles and why modern metal axe heads work better than primitive stone ones. Vogel attributes the success of eighteenth-century American colonists to their invention of axe heads that had the hole for the shaft closer to the cutting edge than in the traditional design at the time; new-style axes were less liable to be twisted by an ill-directed blow. The author tells us why crosscut saws have two kinds of tooth, and big gaps between groups of teeth. And screws, we are told, have right-handed threads because the relative strengths of different arm muscles enable a right-handed person to twist them more forcibly clockwise than anticlockwise. In some places, scientist readers may be frustrated by a lack of detail. For example, they may want a proper explanation of the sweet spot of a hammer or baseball bat, or more information about tests of human strength. However, there are plenty of footnotes and references to the literature.

Vogel regards the wheelbarrow as one of the all-time great inventions. It enables us to move heavier loads than we could carry; it has just three supports, so that it rests steadily on uneven ground; it is highly manoeuvrable; and it offers little resistance to forward movement.

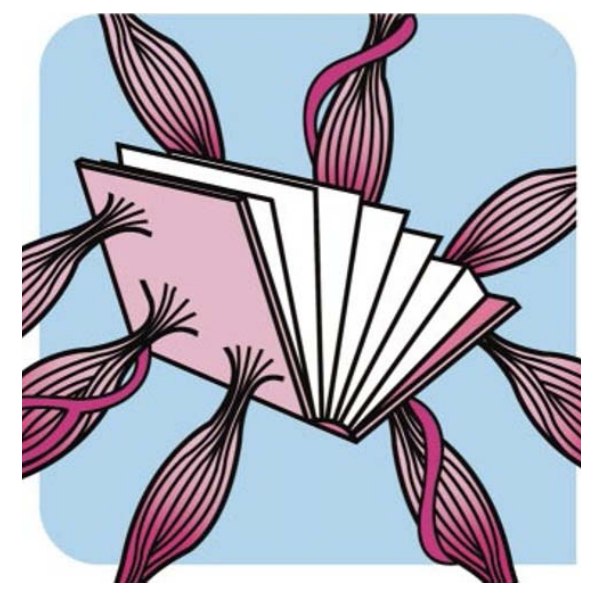

Elsewhere, cycling and rowing are discussed, albeit in less detail than I would have liked, together with less-familiar manpowered vehicles, including the ancient Greek warship known as the trireme, and pedal-powered aircraft.

Vogel gives us a great deal of fascinating discussion of obsolete technology. He discusses the relative merits of horses and oxen as draft animals, and explains the design of harness and of the ingenious whippletree, which makes all the animals in a team pull with equal force. He compares medieval machines for propelling rocks into besieged cities, calculating their ranges and the time needed for reloading. He points out that it would have been best to use the heaviest possible rocks so as to get as much momentum as possible for a given energy input. And he tells us why it made ergonomic sense to cut huge blocks of stone for the pyramids but to make small mud bricks for the Great Wall of China.

Finally, Vogel considers muscle as meat. He compares the energy content of different meats, pointing out the huge differences resulting from their different fat contents. We learn why filet mignon (the psoas muscle) is particularly tender, how best to cook squid, and why (according to cannibals) human flesh tastes like pork, but sweeter.

This is a book that should be enjoyed and understood by intelligent non-scientists as much as by scientists. It offers thoughtful insight into a remarkable range of past and present human activities. Physiologists may want to skip the early chapters and may regret the lack of technical detail, but they, too, should find the book entertaining and illuminating.

R. McNeill Alexander is in the School of Biology,

University of Leeds, Leeds LS2 9JT, UK.

\section{The tale of the \\ human genome}

The Common Thread: A Story of Science, Politics, Ethics and the Human Genome

by John Sulston and Georgina Ferry

Bantam: 2002. 320 pp. 17.99

\section{Sydney Brenner}

Much has been written about the human genome and the project to sequence it, but this is the first book by one of the scientists who played a large part in getting it done. John Sulston, former director of the Sanger Centre at Hinxton near Cambridge, UK, where much of the work was done, has written an account of the project. He tells how he moved from organic chemistry to his decisive research on the cell lineage of the nematode Caenorhabditis elegans, and then 


\section{New Journals}

This year, Nature's annual new journals review supplement will appear in the 7 November issue. Publishers and learned societies are invited to submit journals for review, as well as details of any eligible electronic journals, taking note of the following criteria:

- Journals must have first appeared during or after June 2000 and published at least four separate issues by the end of June 2002.

- Journals covering any aspect of science are eligible, although those dealing with clinical medicine and pure mathematics are excluded, as are newsletters and publications of abstracts.

-Frequency of publication must be at least three times a year.

- The main language must be English.

-Deadline for submissions is 15 July 2002.

For each eligible title, please send at least four different issues (the first, the most recent and any two others), together with full details of subscription rates, to Mary Purton, Nature, The Macrnillan Building, 4 Crinan Street, London N1 9XW, UK. Tel: +44 (0)20 78434567. Fax: +44 (0)20 7843 4596/4763. E-mail: m.purton@nature.com

sequenced its genome with Bob Waterston, before building the large sequencing factory that would work on the human genome. The book is co-written with science journalist Georgina Ferry.

From the very start, the architects of the Human Genome Project found themselves bedevilled by two problems. The first was how to obtain the very large resources required for the sequencing and to ensure the support of the scientific community. Second, they had to deal with several issues that are extraneous to scientific and technical matters, including patenting and the use of human genetic information. Many of those who worked on the project had previous experience of these problems, which arose with the invention of methods of cloning DNA; most of these problems are still with us today.

Many scientists were opposed to the project, partly because they saw sequencing as a mindless activity, but largely because it would be Big Science and that meant Big Money. They were worried that the project would drain resources away from their research, which is why additional support had to be generated that would not compete with existing research funds. Today the project is widely accepted, but at the outset almost everybody involved had to be dragged screaming into it. It was difficalt for most scientists to understand that genome sequencing would give us a new approach to genetics; few had experienced the illumination I had in 1977 on seeing how Fred Sanger's sequence of bacteriophage lambda gave us the amino-acid sequences of the proteins made by all of the genes of its 50-kilobase genome.

Sulston sees the publicproject as a crusade against those bent on creating a monopoly in human genome data by patenting. Chief among these is Craig Venter, who set up The Institute of Genome Research (TIGR), which was financed by Human Genome Sciences, aprivate company that patented the sequences emerging from TIGR's expanded
cDNA sequencingprogramme. The genomics 'goldrush' was created when the rights for these sequences were sold to SmithKline for $\$ 125$ million.

Other companies followed in their wake, including Incyte, which also patented sequences and kept its databases closed to all except paying customers. Sequences of human genes had been patented by many working in the public research sector, but what was new and different in the case of the human genome is that the monopoly might involve every single gene, and thus every singleprotein, in the human body.

In 1998 Venter announced that he was setting up Celera to sequence the human genome, and that he would do it well ahead of the public-sector project by using a total shotgun strategy. The public-sector group had already departed from their original pristine standards of a genome finished to $99.99 \%$ accuracy by contemplating in 1995 the production of a 'draft' sequence. Sulston tells how the public project's work towards the draft sequence was accelerated in response to Celera's challenge, and how Sulston was able to convince the Welloome Trust to increase its funding.

The race was finally declared a draw on 26 June 2000, when a joint announcement was made about the draft sequences obtained by each group. This was followed early in

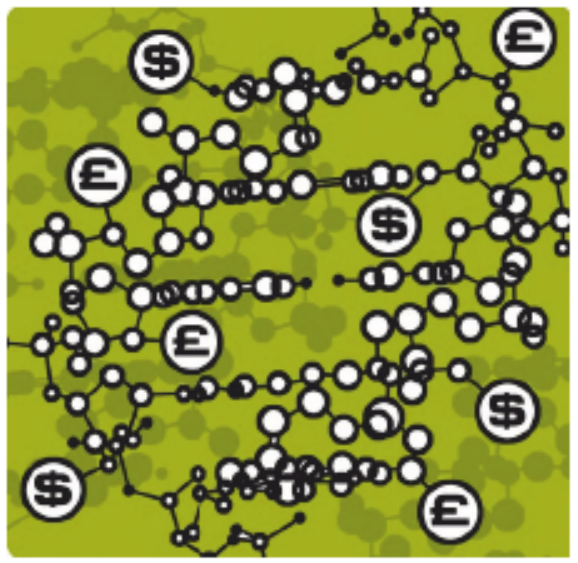

2001 by the publication of two papers, one by Celera in Science, the other by the public project in Nature. Sulston recounts how this exacerbated the angry relations between the groups.

The dominant message in the book is that the human genome sequence belongs to everybody and that we should all have free access to it. Sulston formulated the Bermuda principles, which aimed to ensure this access by the daily automatic release of all sequence assemblies of more than 1 kilobase and the immediate submission of finished sequences to the public databases. The lofty aim was to make the sequence freely available for research and development, but its prior publication also rendered sequences unpatentable for lack of novelty. It did not help the ordinary scientist very much because large computing resources were required to do anything serious with the unfinished sequences. Celera had such resources, and so were able to use the public database as well as their own data.

Sequencing large genomes has nothing to do with any intellectual endeavour. The creative work was done earlier by Fred Sanger and by others who improved the technology. The rest is about two things: money and management. As the various projects developed, their demand for money increased. The nematode sequencing project quickly consumed most of the funds available for genome work at a time when money was short.

Sulston depicts Venter as a man who would sully the human genome by making people pay to use it, a devil who needed to be defeated. There is another view: that he was more Faust than Mephistopheles. He had ambitions in science but was essentially an outsider. His talents for organization were outstanding, but if he were to create a place for himself in the sequencing world he would need resources. He could not get these from the public sector, so he turned to other sources. Commercial organizations expect a return for their money, and Venter not only accepted the faustian bargain but used the deal to try to win the race. It looks like a clever business ploy to sell more machines and use the heightened interest in genome research to raise a large amount of money. Today, the genome bubble has burst and everybody has gone to look for drugs. Will the public sector carry on to finish the human genome sequence?

What $I$ found interesting in this account is that Sulston doesn't tell us anything about the genomes he has sequenced. What did he find there that excited him? What did he learn about genes, about life, about evolution, about worlds to come? It is the play of Hamlet without Hamlet.

Sydney Brenner is at the Salk Institute, La Jolla, California 92037-1099, USA. 